FACTA UNIVERSITATIS

Series: Physical Education and Sport, Vol. 18, No 3, 2020, pp. 535 - 545

https://doi.org/10.22190/FUPES200809051S

Research article

\title{
RELIABILITY AND VALIDITY OF CHANGE-OF-DIRECTION SPEED TESTS FOR JUNIOR BASKETBALL PLAYERS
}

\author{
UDC 796. 012:323.2
}

\author{
Nenad Selaković, Željko Krneta \\ Faculty of Sport and Physical Education, University of Novi Sad, Novi Sad, Serbia
}

\begin{abstract}
The main goal of this study was to determine the reliability and validity of change-of-direction speed (CODS) tests for junior basketball players and to test the differences between the positions of players on the team. On a sample of 66 junior basketball players (18.2 \pm 3.18 years), the CODS was tested using the following tests: the Lane Agility Test (LAT), Zigzag Agility Test (ZAT), Agility T-test and Modified Agility Ttest. Body height and body mass were used as control variables. $\alpha$-Cronbach's coefficient was calculated to determine the reliability and internal consistency of the measurements, as well as the average correlation between the trials of each test. The difference between groups of players was tested by MANCOVA. CODS tests showed good to high reliability (interclass correlations ranged from 0.83-0.93 with a variability of $4.4 \%$ to $6.4 \%$ for the entire sample). The first principal component was determined, which included $83 \%$ of the total variance of the analyzed variables. Very high coefficients of internal validity of all the applied tests (0.93-0.98) were obtained on the common subject of defined measurements. Significant differences were found between groups of players by position in favor of outside players (guards) on two tests LAT and ZAT ( $F=18.023$; 8.559 and $p \leq 0.005)$ with control of the influence of body height and body mass. All tests can be rated as reliable and valid for junior basketball players. LAT proved to be the most suitable for assessing the CODS in young basketball players, with the best discrimination of players by position on the team.
\end{abstract}

Key words: Change-of-Direction Speed, Young Basketball Players, Reliability, Validity, Positional Differences

Received August 09, 2020/ Accepted December 22, 2020

Corresponding author: Željko Krneta

Faculty of Sport and Physical Education, University of Novi Sad, Lovćenska 16, 21000 Novi Sad, Serbia

Phone: + 38121450188 •E-mail: krnetazeljko@yahoo.com

๑ 2020 by University of Niš, Serbia | Creative Commons License: CC BY-NC-ND 


\section{INTRODUCTION}

Basketball is a team sport in which each player coordinates his individual technique and individual tactics with his teammates through the team's collective tactics (Perica, Trninić, \& Jelaska, 2011). Most of the key elements of basketball take place in anaerobic mode with high-intensity activities such as short sprints, rapid changes of direction, jumps, and other movements that come from the Creatine phosphate system (Delextrat \& Coen, 2009). As many as $20.7 \%$ of sprint activities in basketball represent changes in the direction of movement, which indicates the importance of the change-of-direction movement speed among basketball players (Conte et al., 2015; Stojanović et al., 2019). The ability to quickly change direction, while maintaining balance, using a combination of strength, force, and neuromuscular coordination was once defined as agility (Baechle \& Earle, 1994). However, agility is now defined as the ability of a body to move rapidly with a change in direction or speed of movement that occurs in response to an external stimulus (Sheppard \& Young, 2005). This further indicates that agility must be separated into components of perception and speed of decision making on the one hand and change-of-direction speed on the other (Barnes et al., 2007), i.e., these components must be evaluated separately. The change-ofdirection speed (CODS) is mostly under the influence of factors such as the quality of leg muscles, i.e., reactive and explosive power (Young, James, \& Montgomery, 2002; Marković, Dizdar, Jukić, \& Cardinale, 2004; Alemdaroğlu, 2012), individual strength of the legs (Young, Wilson, \& Byrne, 1999) and linear velocity (Sheppard \& Young, 2005; Vesković \& McGuigan, 2008). It was also found that other abilities such as balance and technique of performing motor activities are significantly correlated with the change-of-direction speed (Sayers, 2000; Young \& Farrow, 2006).

The ability to quickly change the direction of movement as a component of agility plays an important role in the structure of the basketball game. The importance of determining the level of CODS is primarily significant in recognizing talent (Pearson, Naughton, \& Torode, 2006). The various field test protocols used to estimate the change-of-direction speed (CODS) must be valid and reliable for practical use. In sports practice, specific tests such as Lane Agility Drill, Reactive Shuttle Test-used in NBA when drafting players are most often used, while the most widely used tests with young players are the standardized Agility T-test (Delextrat \& Coen, 2009; Sekulić, Uljević, Perić, Spasić, \& Kondrić, 2017), Zigzag Drill Test (Bloomfield, Ackland, \& Elliot, 1994; Karalejić \& Jakovljević, 2009) and Y-shaped Agility Test (Lockie, Jeffriess, McGann, Callaghan, \& Schultz, 2014). Although most of these tests contain some of the movement patterns used in basketball (running forward, running backwards and side step movement), different results obtained in the application of these tests in basketball players indicate certain shortcomings in diagnostics of the change of direction movement speed (Paoule, Madole, Garhammer, Lacourse, \& Rozenek, 2000; Delextrat \& Cohen, 2008; Chaouachi et al., 2009; Brown, 2012). In general, the limitation of these tests is primarily reflected in the small number of changes of direction-direction of movement, the distance covered between changes of direction of movement, the total distance traveled and the deficiencies of patterns of movement which occur during a basketball game. It is very important to emphasize that when applying tests to evaluate the CODS one should take into account the position of the player on the team, the level of competition as well as the age category.

Previous research has shown different results in the application of the Agility T-test (Abdelkrim, Chaouachi, Chamari, Chtara, \& Castagna, 2010; Jakovljević, Karalejić, Pajić, 
Gardašević, \& Mandić, 2011; Köklü, Alemdaroğlu, Koçak, Erol, \& Fındıkoğlu, 2011; Sekulić et al., 2017).

Therefore, the main goal of the current study was to determine the reliability and validity of CODS tests for junior basketball players and to test the differences between positions of players on the team.

\section{METHOD}

\section{Participants}

The study included a sample of 66 junior basketball players (18.2 \pm 3.18 years) who had to meet certain requirements: at least 10 games played during the season, attendance on at least $75 \%$ of training sessions during the season, minimum playing experience of 7 years and no serious sports injuries for at least two months before testing. The probabilistic sample included six first-ranked teams of the HEBA single junior league in the 2012/2013 season (B.C. Partizan, B.C. Crvena Zvezda, B.C. Vršac, B.C. Žitko Basket, B.C. Borac, B.C. Sloboda). The teams had approximately the same number of training sessions in the micro cycle (6-8). The entire sample is divided into two sub-samples according to player positions: outside players (point guards and shooting guards and small forwards, $\mathrm{N}=39$ ) and inside players (power forwards and centers, $\mathrm{N}=27$ ). Background data was collected based on a survey completed by the players two days prior to testing.

\section{Measuring Instruments}

Four tests were used to assess the change-of-direction speed: the Lane Agility Test (LAT), Zigzag Agility Test (ZAT), Agility T-test (TT) and Modified Agility T-test (MAT) (National Basketball Conditioning Coaches Association, 2000; Bloomfield et al., 1994; Pauole et al., 2000; Sassi et al., 2009). A system of photocells with a PLC (Unitronics, ACE-Automatic Control Engineering, USA) was used for measurement. Anthropometric measurements included measurements of body height (Seca SE206, UK) and body mass (Tanita BC-540, GER).

\section{Procedures}

The testing was realized in the sports halls where the teams train every day. The players were randomly divided into two groups. Body height and body mass were first measured, after which the examiners performed standard warm-ups consisting of light to moderate running for 5 to 10 minutes, static and dynamic stretching exercises for 5 minutes, shortdistance accelerations with changes of direction, and innervation exercises using agility ladders. After that, testing of motor tasks was performed. The choice of the order of tests was random. Players had three trials for each test with a minimum passive break of 2 minutes between attempts and a break of 5 minutes between each test. All achieved measurement results were recorded in a specially prepared measurement sheet in units (1/100 second). The players started the test from a standing position with their feet placed $20 \mathrm{~cm}$ behind the starting line.

Lane Agility Drill (Figure 1). The player stands in a standing position behind the starting line, facing the base line of the basketball court. On the examiner's mark, the player sprints forward towards the baseline to cone $\mathrm{B}(5.8 \mathrm{~m})$. Then he slides sideways to cone $\mathrm{C}$ ( $\mathrm{B}$ to $\mathrm{C}$ 
$4.9 \mathrm{~m})$ where he starts running backwards to cone D $(5.8 \mathrm{~m})$ and then slides sideways to cone A $(4.9 \mathrm{~m})$. When the player steps on the line that is an extension of the side line of the paint, he returns in the opposite direction, by sliding sideways. Recording time stops when the player reaches the starting position again.

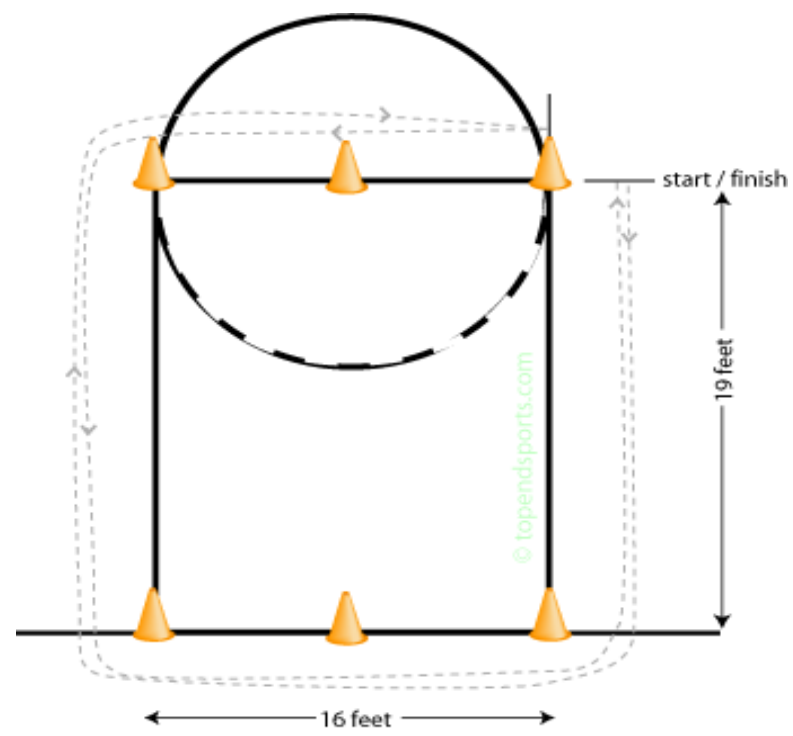

Fig. 1 Lane Agility Test

Zigzag Agility Test (Figure 2). The player assumes a standing position behind the starting line of cone 1 . On the examiner's mark, the player sprints diagonally towards the free throw line to cone 2 . Then sprints to right to cone 3 and to cone 4 and at the end of the sprint to cone 1, i.e., the starting position. The time stops when the player crosses the starting line-level of cone 1 .

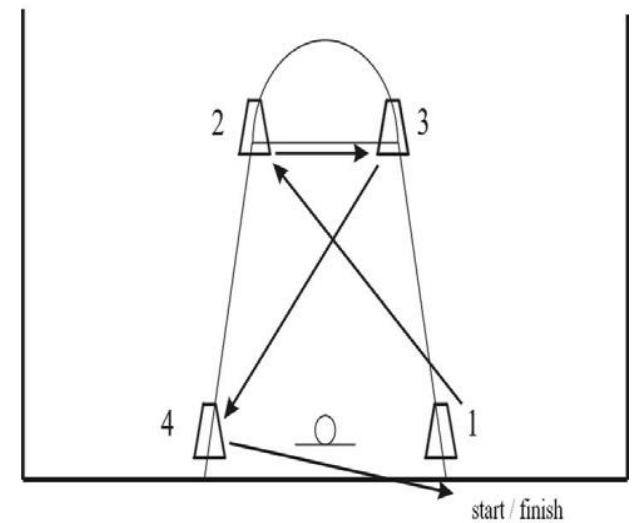

Fig. 2 Zigzag Agility Test 
Agility T-Test (Figure 3). The player assumes a standing position behind the starting line. On the examiner's mark, the player sprints to cone B, touches it with his right hand. After he slides sideways towards cone $\mathrm{C}$ and touches it with his left hand. After he slides sideways to cone $\mathrm{D}$ and touches it with his right hand. He slides sideways again towards cone B, touches it with his left hand and runs backwards towards cone A. Recording time stops when the player crosses the line of cone A.

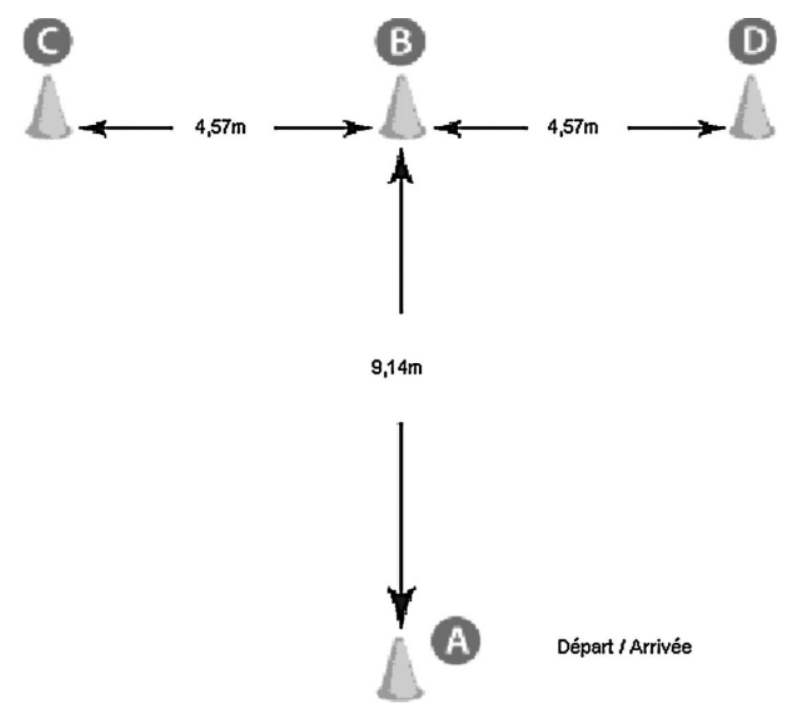

Fig. 3 Agility T-Test

Modified Agility T-test (Figure 4). The test is performed in the same way as the Agility T-test with the only difference in the total distance crossed in the test.

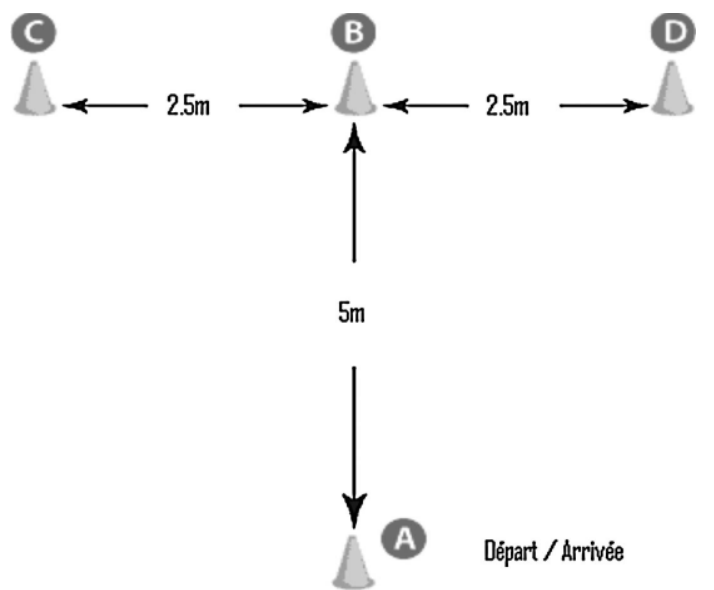

Fig. 4 Modified Agility T-Test 


\section{Statistical Data Analyses}

The following basic central and dispersion parameters of the results were calculated for all variables and measurement particles: arithmetic mean (M), standard deviation (SD), skewness (Skew) and kurtosis (Kurt). The coefficient of variability for the average values of the variables was also calculated separately for each group (CV). Using the KolmogorovSmirnov test, the normality of the distribution of results was tested. The average result from the three measurement sessions was determined for all participants in the analyzed variables, and was used in the further analysis of the internal validity of the tests.

To determine the reliability and internal consistency of the measurements, $\alpha$-Cronbach's coefficient was calculated, as well as the average interclass correlation between the trials of each test (ICC), as a measure of the homogeneity of the composite motor test. The first principal component was determined from the test measurement trials by the principal component method $(\mathrm{H})$. Correlations of the measurement trials with the principal component were used to assess the internal validity of the measurement trials in the analyzed tests. The internal validity of the tests was determined by the principal component method (PCA) based on the correlations of the tests with the principal component. The difference between groups of players in test results was tested by the Multivariate Analysis of Covariance (MANCOVA), with control of body height and body mass. Data analysis was performed using IBM SPSS software package, version 20 .

\section{RESULTS}

The results of the Kolmogorov-Smirnov test show that the distribution of the results in all variables does not deviate statistically significantly from the normal distribution (Table 1).

Table 1 Data distribution characteristics for the entire sample

\begin{tabular}{lcccc}
\hline Variables & Skew & Kurt & KS (z) & KS (p) \\
\hline Body height & 0.28 & -0.41 & 0.75 & 0.62 \\
Body mass & 0.59 & 0.57 & 0.95 & 0.33 \\
\hline Lane agility Test & 0.16 & -0.36 & 0.49 & 0.97 \\
Zigzag agility Test & 0.42 & 0.93 & 0.84 & 0.49 \\
Agility T-test & 0.44 & -0.55 & 0.92 & 0.37 \\
Modified T-test & 0.70 & 0.42 & 1.01 & 0.26 \\
\hline
\end{tabular}

Legend: Skew-skewness; Kurt-Kurtosis; KS-Kolmogorov-Smirnov Test: z-Value, p-Significance.

The asymmetry of the distribution was not disturbed in any of the analyzed variables (Skew). The homogeneity of the distribution of the results (Kurt) indicates greater homogeneity of the participants or reduced discrimination in the ZAT and MAT tests $(0.418 ; 0.931)$ while in the LAT and TT tests a reduced homogeneity of the results was observed $(-0.355 ;-0.555)$.

Significant homogeneity of the results was observed in all measurement trials of the analyzed tests, which indicates high homogeneity of the sample of participants (Table 2). 
Table 2 Descriptive statistics and indicators of reliability and validity of analyzed tests

\begin{tabular}{|c|c|c|c|c|c|c|c|c|c|c|}
\hline \multirow[t]{2}{*}{ Variable } & \multirow[t]{2}{*}{ Trials } & \multicolumn{3}{|c|}{ Outside players } & \multicolumn{3}{|c|}{ Inside players } & \multirow[b]{2}{*}{$\mathrm{H}$} & \multirow[b]{2}{*}{$\alpha$} & \multirow[b]{2}{*}{ ICC } \\
\hline & & M & $\mathrm{SD}$ & $\mathrm{CV}$ & M & $\mathrm{SD}$ & $\mathrm{CV}$ & & & \\
\hline Body height $(\mathrm{cm})$ & & 189.30 & 6.34 & & 198.38 & 7.84 & & & & \\
\hline Body mass (kg) & & 79.52 & 7.06 & & 93.26 & 9.49 & & & & \\
\hline \multirow{4}{*}{$\begin{array}{l}\text { Lane Agility Test } \\
\text { (s) }\end{array}$} & 1 & 12.07 & 0.83 & & 13.18 & 0.87 & & 0.98 & \multirow{4}{*}{0.97} & \multirow{4}{*}{0.93} \\
\hline & 2 & 11.80 & 0.73 & & 12.79 & 0.82 & & 0.98 & & \\
\hline & 3 & 11.72 & 0.76 & & 12.64 & 0.75 & & 0.97 & & \\
\hline & Average & 11.87 & 0.76 & 6.40 & 12.87 & 0.78 & 6.10 & & & \\
\hline \multirow{4}{*}{$\begin{array}{l}\text { Zigzag Agility Test } \\
\text { (s) }\end{array}$} & 1 & 5.92 & 0.32 & & 6.22 & 0.31 & & 0.95 & \multirow{4}{*}{0.95} & \multirow{4}{*}{0.87} \\
\hline & 2 & 5.83 & 0.27 & & 6.17 & 0.28 & & 0.96 & & \\
\hline & 3 & 5.80 & 0.24 & & 6.16 & 0.35 & & 0.95 & & \\
\hline & Average & 5.85 & 0.26 & 4.40 & 6.19 & 0.30 & 4.80 & & & \\
\hline \multirow{4}{*}{ Agility T-test (s) } & 1 & 9.22 & 0.46 & & 9.71 & 0.50 & & 0.95 & \multirow{4}{*}{0.96} & \multirow{4}{*}{0.90} \\
\hline & 2 & 9.08 & 0.50 & & 9.59 & 0.52 & & 0.98 & & \\
\hline & 3 & 9.08 & 0.61 & & 9.58 & 0.54 & & 0.96 & & \\
\hline & Average & 9.13 & 0.50 & 5.50 & 9.63 & 0.50 & 5.20 & & & \\
\hline \multirow{4}{*}{ Modified T-test (s) } & 1 & 5.60 & 0.39 & & 5.89 & 0.40 & & 0.93 & \multirow{4}{*}{0.93} & \multirow{4}{*}{0.83} \\
\hline & 2 & 5.44 & 0.28 & & 5.77 & 0.40 & & 0.96 & & \\
\hline & 3 & 5.44 & 0.32 & & 5.75 & 0.36 & & 0.93 & & \\
\hline & Average & 5.50 & 0.31 & 5.60 & 5.80 & 0.37 & 6.40 & & & \\
\hline
\end{tabular}

Legend: $\mathrm{M}=$ arithmetic mean; $\mathrm{SD}=$ Standard Deviation; $\mathrm{CV}=$ Coefficient of Variability;

$\mathrm{H}=$ Correlations of the Measurement Trials with the Main Component; $\alpha=$ Cronbach's Alpha Coefficient; $\mathrm{ICC}=$ Interclass Correlation Coefficients.

Cronbach's reliability coefficients $(\alpha)$ show that all four applied tests have high reliability with coefficients in the range of $0.93-0.97$. Correlations of particles with the first principal component are high and indicate good internal validity of measurements $(\mathrm{H}=0.96-0.98)$. The second measurement trial has the highest correlation with the first subject of measurement in all tests. The ICC are high and show that all measurement trials have the same subject of measurement, i.e., high homogeneity (0.83-0.93).

The correlations of the analyzed variables were high and statistically significant, and the PCA isolated one characteristic root that describes $83 \%$ of the total variance of the analyzed variable. The correlations of the analyzed variables with the first main component varied between 0.87 and 0.93 and indicates a well-defined common subject of measurement in the applied tests. The TT and LAT showed the greatest validity (0.94 and 0.93 respectively). Only the MAT had a lower correlation with the first main component.

The examination of the total differences between outside and inside players with control of body height and mass showed the presence of a statistically significant difference $(\mathrm{F}=5.75 ; \mathrm{p}=0.001)$ with a high effect of the difference $\left(\mathrm{Eta}^{2}=0.28\right)($ Table 3$)$.

Table 3 Results of the analysis of covariance

\begin{tabular}{lccccc}
\hline Variables & $\mathrm{M} 1$ & $\mathrm{M} 2$ & $\mathrm{~F}$ & $\mathrm{p}$ & $\mathrm{Eta}^{2}$ \\
\hline LAT (s) & 11.8 & 12.87 & $18.02^{* *}$ & 0.001 & 0.23 \\
ZAT (s) & 5.85 & 6.19 & $8.56^{* *}$ & 0.005 & 0.12 \\
TT (s) & 9.13 & 9.63 & 5.14 & 0.027 & 0.08 \\
MAT (s) & 5.49 & 5.80 & 6.66 & 0.012 & 0.10 \\
\hline \multicolumn{5}{c}{ Legend: F-Ratio; p-Level of Significance; Partial Eta ${ }^{2}$-Effect Size. }
\end{tabular}


Thereby, a significant influence of body mass on the results of all tests was observed $(p=0.022 ; 17.4 \%$ variance). An individual influence of the position in the team, with a Bonferroni corrected alpha level of 0.0125 , was obtained in the tests LAT and ZAT with an explanation of $22.5 \%$ and $12 \%$ of the variance difference, respectively.

\section{DISCUSSION}

This study explored the reliability and factor validity of four tests of CODS that are often used in practice with elite young basketball players. All analyzed tests showed high reliability of measurement results. Previously obtained high Cronbach's $(\alpha)$ coefficients, ICC and moderate variability of the results $(\mathrm{CV})$ on a sample of students, football players and students of sports studies in relation with TT and MAT confirm the reliability of measurement results obtained in this study (Stewart, Turner, \& Miller, 2012; Sassi et al., 2009; Sekulić, Spasić, Mirkov, Čavar, \& Sattler, 2013; Sporiš, Jukić, Milanović, \& Vučetić, 2010). Furthermore, other research results (Chaouachi et al., 2009; Brown, 2012; Stojanović et al., 2019) show a very high reliability of test measurement results used for the assessment of CODS in basketball players.

A more detailed comparison of our and results from previous research is difficult given the application of different protocols (tests) and the generally insufficient number of studies that examined changes in the direction of movement in a sample of basketball players. The $\mathrm{CV}$ of the results obtained in this study deviates minimally from the results obtained in Brown's study (2012), while slightly lower values of CV were obtained in some other studies (Pauole et al., 2000; Chaouachi et al., 2009; Sassi et al., 2009; Stewart et al., 2012). This can be elucidated by the differences in the sample by age and entities that were not basketball players in the given research. Slightly higher CV values in the LAT and MAT test compared to the TT and ZAT can be explained by greater complexity of the task in LAT because it contains changes of direction, lateral movements in posture and running backwards, while the $\mathrm{CV}$ in the MAT test can be explained by the shorter duration of the test as well as changes in the direction of movement on a smaller area.

High correlations of the measurement trials with the first principal component were found, which indicated a good internal validity of the trials. In all the test measurement trials, a result stabilization tendency was observed in the second performance, which was obtained on a similar sample in the study of Stojanović and associates (2019). On the other hand, the low variability in the ZAT test can be explained by the "simplicity" of the motor task, while in the TT test it can be explained by previous knowledge or acquaintance with this test (4.4-4.8\% and 5.2-5.5\%), which was confirmed by studies (Chaouachi et al., 2009; Brown, 2012) on a sample of basketball players.

The obtained moderate to high positive correlations between all applied tests $(0.671$ $0.867)$ coincide with the results of previous research in tests that are commonly used to assess the CODS in basketball players (Brown, 2012; Stojanović et al., 2019) but also in a sample of university athletes (Pauole et al., 2000; Sassi et al., 2009; Sekulić et al., 2013). A slightly weaker correlation of the MAT test with the LAT and ZAT tests could indicate slightly lower metabolic requirements $(5.50 \mathrm{~s})$ as well as the number of changes of direction of movement.

The first principal component of the sample of applied tests covered $83 \%$ of the total variance. The correlation of the tests with the first principal component showed that all of 
the tests used are good for assessing the CODS in young basketball players. In addition to being used in discovering talents, the applied tests can also be used in training to improve this component of agility.

Furthermore, when assessing the CODS, the positions of the players in the team and their body constitution must be taken into account. This is indicated by statistically significant differences between positions of the players in the team obtained in this research. The obtained results suggest that the LAT and the ZAT provide good discrimination of players according to their positions in the team, with the control of effects of body height and mass. Similar differences were obtained in studies dealing with this topic (Bloomfield et al., 1994; Chaouachi et al., 2009; Sporiš et al., 2010; Jakovljević et al., 2011; Erčulj, Brančić, \& Jakovljević, 2011; Brown, 2012; Mitić et al., 2019), but without control of effects of body mass and height on test results. A logical explanation for the obtained differences can be found in the data on the intensity of basketball players' activity during the game where outside players (point guards and shooting guards and small forwards) carry out and realize a much larger number of changes of direction of movement and high intensity movements than inside players (forwards and centres) (McInnes, Carlson, Jones, \& McKenna, 1995; Abdelkrim, Fazaa, Ati, \& Tabka, 2007). The very structure of the tests influenced the differences between the groups of players and is reflected in the complexity of the task, which includes the number of changes in direction, manner of movement and the total distance covered in the test.

\section{CONCLUSION}

The results of the current study confirmed the reliability and validity of all applied tests of the CODS specific to basketball. Only the LAT test showed a learning effect, while the other three tests did not. Significant strong correlations between all change-of-direction speed tests in this study showed that each test measured the same ability of junior basketball players. The LAT test was the most sensitive in identifying differences between positions of the players in the team where it explained $22 \%$ of the total variance with the elimination of differences in the two anthropometric variables (body height and body mass). Also, the application of these tests in practice is very simple and does not require major monetary investment. In the end, although all analyzed tests in this study showed excellent reliability and validity for junior basketball players, future research should examine and consider their limitations in terms of the construction of the test on a sample which differs by gender, level of competition and experience to obtain long-term validity.

\section{REFERENCES}

Abdelkrim, N.B., Fazaa, S.E., Ati, J.E., \& Tabka, Z. (2007). Time-motion analysis and physiological data of elite under-19-year-old basketball players during competition. British Journal of Sports Medicine, 41(2), 69-75.

Abdelkrim, N. B., Chaouachi, A., Chamari, K., Chtara, M., \& Castagna, C. (2010). Positional role and competitive-level differences in elite-level men's basketball players. The Journal of Strength \& Conditioning Research, 24(5), 1346-1355.

Alemdaroğlu, U. (2012). The relationship between muscle strength, anaerobic performance, agility, sprint ability and vertical jump performance in professional basketball players. Journal of Human Kinetics, 31(1), 149-158.

Baechle, T.R., \& Earle, R.W. (1994). Essentials of strength training and conditioning. Champaign, IL: Human Kinetics. 
Barnes, J.L., Schilling, B.K., Falvo, M.J., Weiss, L.W., Creasy, A.K., \& Fry, A.C. (2007). Relationship of jumping and agility performance in female volleyball athletes. The Journal of Strength and Conditioning Research, 21(4), 1192-1196.

Bloomfield, J., Ackland, T., \& Elliot, B.C. (1994). Applied anatomy and biomechanics in sport. Melbourne: Blackwell Scientific Publications.

Brown, A.E. (2012). The reliability and validity of the lane agility test for collegiate basketball players (Doctoral dissertation)

Chaouachi, A., Brughelli, M., Chamari, K., Levin, G.T., Abdelkrim, N. B., Laurencelle, L., et al. (2009). Lower limb maximal dynamic strength and agility determinants in elite basketball players. Journal of Strength and Conditioning Research, 23(5), 1570-1577.

Conte, D., Favero, T.G., Lupo, C., Francioni, F.M., Capranica, L., \& Tessitore, A. (2015). Time-motion analysis of Italian elite women's basketball games: individual and team analyses. The Journal of Strength and Conditioning Research, 29(1), 144-150.

Delextrat, A., \& Cohen, D. (2008). Physiological testing of basketball players: Toward a standard evaluation of anaerobic fitness. Journal of Strength and Conditioning Research, 22(4), 1066-1072.

Delextrat, A., Cohen, D. (2009). Strength, power, speed, and agility of women basketball players according to playing position. Journal of Strength and Conditioning Research, 23(7), 1974-1981.

Erčulj, F., Brančić, M., \& Jakovljević, S. (2011). The level of speed and agility of different types of elite female basketball players. Facta Universitatis Physical Education and Sport, 9(3), 283-293.

Jakovljević, S., Karalejić, M., Pajić, Z., Gardašević, B., \& Mandić, R. (2011). The influence of anthropometric characteristics on the agility abilities of 14 year-old elite male basketball players Facta Universitatis Series Physical Education and Sport, 9(2), 141-149.

Karalejić, M., \& Jakovljević, S. (2009). Dijagnostika u košarci (Diagnostics in basketball). Belgrade: 3D plus VSZŠ. In Serbian

Köklü, Y., Alemdaroğlu, U., Koçak, F., Erol, A., \& Fındıkoğlu, G. (2011). Comparison of chosen physical fitness characteristics of Turkish professional basketball players by division and playing position. Journal of Human Kinetics, 30(1), 99-106.

Lockie, R., Schultz, A., Callaghan, S., Jeffriess, M., \& Berry, S. (2013). Reliability and validity of a new test of Change-of-Direction Speed for field- based sports: The Change-of-Direction and Acceleration Test (CODAT). Journal of Sports Science and Medicine, 12(1), 88-96.

Marković, G., Dizdar, D., Jukić, I., \& Cardinale, M. (2004). Reliability and factorial validity of squat and countermovement jump tests. The Journal of Strength and Conditioning Research, 18(3), 551-555.

McInnes, S., Carlson, J., Jones, C., \& McKenna, M. (1995). Physiological load imposed on basketball players during competition. Journal of Sports Sciences, 13(5), 387-397.

Mitić, M., Paunović, M., Živković, M., Stojanović, N., Bojić, I., \& Kocić, M. (2019). Differences in agility and explosive power of basketball players in relation to their positions on the team. Facta Universitatis Series Physical Education and Sport, 16(2), 739-747.

National Basketball Conditioning Coaches Association. (2007). Complete conditioning for basketball. Champaign, IL: Human Kinetics.

Pauole, K., Madole, K., Garhammer, J., Lacourse, M., \& Rozenek, R. (2000). Reliability and validity of the Ttest as a measure of agility, leg power, and leg speed in college-aged men and women. The Journal of Strength and Conditioning Research, 14(4), 443-450.

Pearson, D.T., Naughton, G.A., \& Torode, M. (2006). Predictability of physiological testing and the role of maturation in talent identification for adolescent team sports. Journal of Science and Medicine in Sport, 9(4), 277-287.

Perica, A., Trninić, S., \& Jelaska, I. (2011). Introduction into the game states analysis system in basketball. Fizička kultura, 65(2), 51-78.

Sassi, R.H., Dardouri, W., Yahmed, M.H., Gmada, N., Mahfoudhi, M.E., \& Gharbi, Z. (2009). Relative and absolute reliability of a modified agility T-test and its relationship with vertical jump and straight sprint. Journal of Strength and Conditioning Research, 23(6), 1644-1651.

Sayers, M. (2000). Running techniques for field sports players. Sports Coach, 23(1), 26-27.

Sekulić, D., Spasić, M., Mirkov, D., Čavar, M., \& Sattler, T. (2013). Gender-specific influences of balance, speed, and power on agility performance. Journal of Strength and Conditioning Research, 27(3), 802-811.

Sekulić, D., Uljević, O., Perić, M., Spasić, M., \& Kondrić, M. (2017). Reliability and factorial validity of nonspecific and tennis-specific pre-planned agility tests: Preliminary analysis. Journal of Human Kinetics, 55(1), 107-116.

Sheppard, J., \& Young, W. (2005). Agility literature review: Classifications, training and testing. Journal of Sports Sciences, 24(9), 919-932. 
Sporiš, G., Jukić, I., Milanović, L., \& Vučetić, V. (2010). Reliability and factorial validity of agility tests for soccer players. Journal of Strength and Conditioning Research, 24(3), 679-686.

Stewart, P.F., Turner, A.N., \& Miller, S.C. (2014). Reliability, factorial validity, and interrelationships of five commonly used change of direction speed tests. Scandinavian Journal of Medicine and Science in Sports, 24(3), 500-506.

Stojanović, E., Aksović, N., Stojiljković, N., Stanković, R., Scanlan, A.T., \& Milanović, Z. (2019). Reliability, usefulness, and factorial validity of change-of-direction speed tests in adolescent basketball players. The Journal of Strength and Conditioning Research, 33(11), 3162-3173.

Vesković, J.D., \& McGuigan, M.R. (2008). Relationships between sprinting, agility, and jump ability in female athletes. Journal of Sports Sciences, 26(3) 97-107.

Young, W.B., James, R., \& Montgomery, I. (2002). Is muscle power related to running speed with change of direction? Journal of Sports Medicine and Physical Fitness, 43(3), 282.

Young, W., \& Farrow, D. (2006). A review of agility: Practical applications for strength and conditioning. Strength and Conditioning Journal, 28(5), 24.

Young, W., Wilson, G., \& Byrne, C. (1999). Relationship between strength qualities and performance in standing and run-up vertical jumps. Journal of Sports Medicine and Physical Fitness, 39(4), 285-293.

\section{POUZDANOST I VALJANOST TESTOVA BRZINE PROMENE PRAVCA KRETANJA KOŠARKAŠA JUNIORA}

Glavni cilj ove studije bio je da se utvrdi pouzdanost $i$ valjanost testova brzine promene pravca kretanja (CODS) košarkaša juniora i ispitivanje razlika između pozicija igrača u timu. Na uzorku od

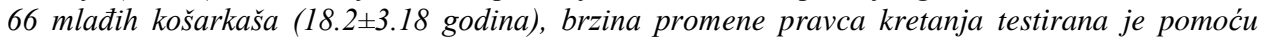
sledećih testova: Lane Agility Test (LAT), Zigzag Agility Test (ZAT), Agility T-test i Modified Agility $T$-test. Kao kontrolne varijable korišćene su telesna visina i telesna masa. Igrači su imali 3 pokušaja da sprovedu svaki od testova. Koeficijent $\alpha$-Cronbach je izračunat da bi se utvrdila pouzdanost $i$ unutrašnja konzistentnost merenja, kao i prosečna korelacija između ispitivanja svakog od testova. Razlika između grupa igrača u rezultatima testa ispitivana je analizom MANOVA. Obrada podataka sprovedena je pomoću softverskog paketa IBM SPSS, verzija 20. Svi CODS testovi pokazali su dobru do visoku pouzdanost (međuklasne korelacije kretale su se od 0.83-0.93 sa varijabilnošću od 4.4\% do $6.4 \%$ za ceo uzorak). Metodom glavne komponente utvrđena je prva glavna komponenta koja je obuhvatala $83 \%$ ukupne varijanse analiziranih varijabli. Na zajedničkom predmetu definisanih merenja dobijeni su vrlo visoki koeficijenti interne validnosti svih primenjenih testova (0.93-0.98). $U$ dva testa LAT i ZAT ( $F=18.023$; 8.559 i $p \leq 0,005)$, kontrolom uticaja telesne visine i telesne mase, utvrđene su statistički značajne razlike između grupa igrača po pozicijama u korist spoljnih igrača. Svi testovi se mogu oceniti kao pouzdani i valjane za košarkaše juniore. LAT se pokazao najpogodnijim za procenu CODSa mladih košarkaša, uz najbolju diskriminaciju igrača prema pozicijama u timu.

Ključne reči: Brzina promene pravca, mladi košarkaši, pouzdanost, valjanost, razlike prema poziciji 